\title{
Molecular and Morphological Identification of Xiphinema hunaniense on the Juniperus chinensis Imported from Thailand
}

\author{
Long $\mathrm{H}^{1,2,3}$, Ling $X Y^{1,3}$, Li FR ${ }^{1,2,3}$, Li YN $N^{1,2,3}$ and Zheng $Y^{1,2,3}$
}

\footnotetext{
${ }^{1}$ Shenzhen Entry-exit Inspection and Quarantine Bureau, Shenzen, 518045 Guangdong P.R., China

${ }^{2}$ State Key Quarantine Laboratory of Legume Pest \& Plant Pathogenic Fungi of AQSIQ, Shenzhen, 518045 Guangdong P.R., China

${ }^{3}$ Shenzhen Key Laboratory of Inspection Research \& Development of Alien Pests, Shenzhen, 518045 Guangdong P.R., China
}

Long H, Ling XY, Li FR, Li YN, Zheng Y 2014 - Molecular and Morphological Identification of Xiphinema hunaniense on the Juniperus chinensis Imported from Thailand. Plant Pathology \& Quarantine 4(2), 92-98, Doi 10.5943/ppq/4/2/3

\begin{abstract}
A population of alien nematode was collected from the roots of Chinese juniper (Juniperus chinensis). The morphology and morphometrical traits of the collected females were in agreement with these of Xiphinema hunaniense described in the original references, except for a few differences, such as the tail length and "c" ratio. The sequences searching and alignment and phylogenetic analysis, which were based on the DNA sequence of D2-D3 expansion regions of 28S rDNA gene, further suggested that the species of this isolated nematode is $X$. hunaniense. In China, it is the first time that $X$. hunaniense was intercepted from this new host imported from Tailand.
\end{abstract}

Key words - Alien nematode- Xiphinema hunaniense- Chinese juniper- morphologyphylogenetic analysis

\section{Introduction}

Xiphinema hunaniense Wang \& Wu, 1992 was first described from vineyard soils in Hunan province, China (Wang \& Wu, 1992). This species is morphologically close to $X$. radicicola Goodey, 1936 and X. brasiliense Lordello, 1951. X. hunaniense was once considered as a junior synonym of $X$. radicicola (Loof et al., 1996). But this view was denied by Robbins \& Wang (1998). Instead they re-established $X$. hunaniense a valid species. Zheng \& Brown (1999) further established the validity of the taxonomic status of $X$. hunaniense based on comparing two $X$. hunaniense populations from different hosts in Hangzhou, China with syntype and paralectotype specimens of X. Radicicola (Cohn \& Sher, 1972; Luc, 1981).

$X$. hunaniense has been reported in some Chinese provinces (Wu et al., 2007). The reported hosts included grape (Vitis vinifera), buntan (Citrus grandis), Chinese hibiscus (Hibiscus rosasinensis), Japanese camellia (Camellia japonica), litchi (Litchi chinensis), longan (Euphoria longana), loquat (Eriobotrya japonica), mango (Mangifera indica), pear (Pyrus pyrifolia var. yokoyama), pine (Pinus sp.), sago palm (Cycas revolute), sweet orange (Citrus sinensis) and some bonsai plants (Camellia sasanpua, Ligustrum quihoui) (Wu et al., 2007). Chen et al. (2004) reported eight populations of $X$. hunaniense colleted from different host plants in Taiwan, China, and discussed the variations of different $X$. hunaniense populations. Wu et al. (2007) described a $X$. 
hunaniense population found in Zhejiang, China, and released the molecular data (Wu et al., 2007).

In this paper, a population of $X$. hunaniense was firstly intercepted by Shenzhen Entry-Exit Inspection and Quarantine Bureau on Chinese juniper (Juniperus chinensis) that imported from Tailand. And the morphological characterization and molecular data of the female $X$. hunaniense population on this new host were presented and compared with the ones from China.

\section{Materials \& Methods}

\section{Morphological characterization}

Specimens of $X$. hunaniense used in this study were isolated and collected from the infested soil and root of Juniperus chinensis that were imported from Tailand with the decanting and sieving method of Brown \& Boag (1988). Nematodes were handpicked from the samples, killed by gentle heat, fixed in a solution of $4 \%$ of formaldehyde $+1 \%$ glycerol, and treated with glycerol according to reported method (Hooper, 1986). All observations of fixed nematodes were under a Zeiss Image.M1 light microscope, whereas photographs and measurements were taken with the software Axiovision 4.7 (Zeiss, Germany). Abbreviations used in Table 1 are defined in Siddiqi (2000).

\section{Molecular identification}

Nematode DNA was extracted from single individuals. One nematode was moved to a clean glass slide, suspended in a 12- $\mu$ d drop of lysis buffer (1XEx Taq buffer, $100 \mu \mathrm{g} / \mathrm{ml}$ proteinase K, 2 $\mathrm{mM} \mathrm{MgC1}_{2}$ ) and cut into fragments. The fragments together with the lysis buffer were then transferred into a $0.2 \mathrm{ml}$ sterile eppendorf tube. After freezing at $-70^{\circ} \mathrm{C}$ for $10 \mathrm{~min}$, tubes were incubated at $60^{\circ} \mathrm{C}$ for $60 \mathrm{~min}$, then at $95^{\circ} \mathrm{C}$ for $15 \mathrm{~min}$. The treatment solution above were then served as DNA sample for PCR. For PCR reaction, $10 \mu \mathrm{l}$ of the DNA sample was added to the PCR reaction mixture containing 1X Ex Taq buffer, $0.2 \mathrm{mM}$ of each dNTPs, $2.0 \mathrm{mM} \mathrm{MgCl}$, $1 \mathrm{U}$ Ex Taq polymerase (TaKaRa Ex Taq ${ }^{\circledR}$, TaKaRa, Dalian, China), $0.4 \mu \mathrm{M}$ of each the primers D2A (5'ACAAGTACCGTGAGGGAAAGTTG-3') and D3B (5'-TCGGAAGGAACCAG CTACTA-3') (synthesized by Sangon Technology \& Services, Shanghai, China) and double-distilled water was added to a final volume of $50 \mu \mathrm{l}$. PCR amplification was followed the program: initial denaturation at $94^{\circ} \mathrm{C}$ for $4 \mathrm{~min}, 40$ cycles at $94^{\circ} \mathrm{C}$ for $30 \mathrm{sec}, 55^{\circ} \mathrm{C}$ for $40 \mathrm{sec}$, and $72^{\circ} \mathrm{C}$ for $1 \mathrm{~min}$ followed by an extension at $72^{\circ} \mathrm{C}$ for $10 \mathrm{~min}$. After DNA amplification, PCR product was checked by running on a $1.5 \%$ agarose gel with $5 \mu \mathrm{l}$ of each PCR product. The other PCR products of five samples were sequenced by Shanghai Sangon Biological Engineering Technology \& Service Co., Ltd..The DNA sequences were edited with the BioEdit (v7.0) (Hall, 1999) and submitted to the GenBank database (www.ncbi.nlm.nih.gov) under accession number KF290564.

\section{Phylogenetic analysis}

28S rDNA gene sequences of $X$. hunaniense in this study and those of related species from GenBank database (www.ncbi.nlm.nih.gov) were used for phylogenetic re-construction, and Longidorus elongatus (AY601578) as outgroup taxa. The newly obtained and published sequences for each gene were aligned using Clustal W (Thompson et al., 1994) with default parameters. Sequence alignments were manually edited using BioEdit (Hall, 1999). Phylogenetic and molecular evolutionary analyses were conducted using MEGA version 5 (Tamura et al., 2011).

\section{Results}

\section{Morphological characters and morphometrics}

A total of 12 female specimens were examined. Morphology and morphometrics of them fit closely to those of the original descriptions of the species that Wang and Wu reported (Wang \& Wu, 1992). As presented in Figs. 1, the female body is hook-shaped (Figs. 1a). It has one long mucro on the middle of tail terminal (Figs. 1e). And the posterior genital tract has only one ovary (Figs. 1c) comparing to the descriptions in the original literature that it divided into two ovarian branches 
(Wang \& Wu, 1992). Additionally, a few females whose vagina slope backwards was observed (Figs. 1d). Males were not found in this population.

The new Thailand population of $X$. hunaniense on Juniperus chinensis in the current study and several other populations reported from China was compared in Table 1. The ranges of morphometric variation are: L (1.73-2.50), a (35-57), b (4.6-8.2), c (29.2-63), c'(1.0-2.9), V\% (21.6-2.9), odontostyle (96-123.3), odontophore (54-75.8), stylet (155.2-195.0), tail (31.1-77.4), width at lip region (8.7-13.5), width at mid. body (37-63.8), width at anus (21.3-35.6).

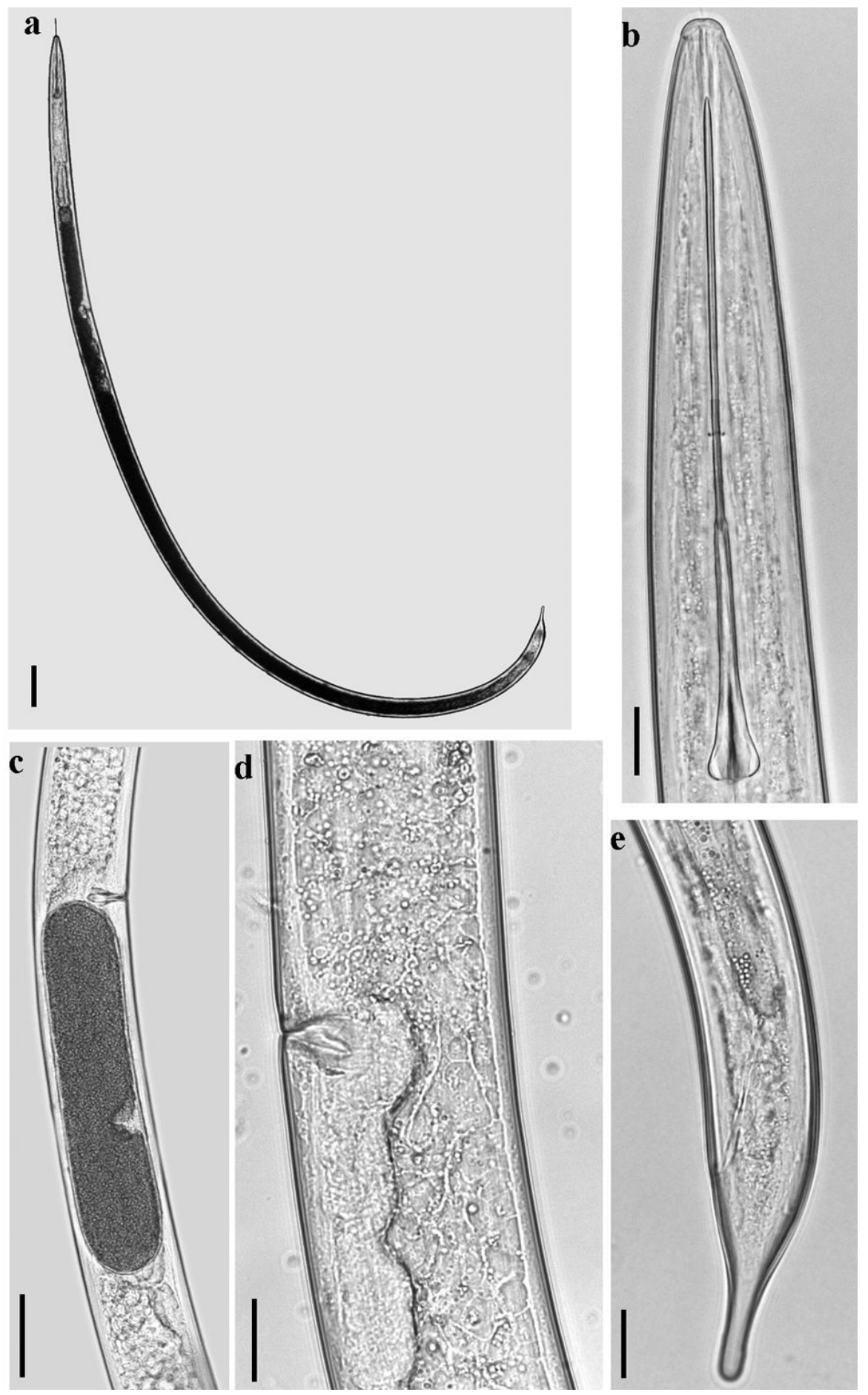

Figs 1 -Light microscopy micrographs of Xiphinema hunaniense female detected from Thailand. a Entire female. $b$ Head regions of female. c-d Vulva of female; e Tail regions of female. (Scale bars: $\mathrm{a},=100 \mu \mathrm{m} ; \mathrm{c}=50 \mu \mathrm{m} ;$ all others $=20 \mu \mathrm{m})$. 


\section{Molecular characterization and phylogenetic relationships of Xiphinema hunaniense}

The amplification of D2-D3 expansion segments of 28S rDNA yielded a single fragment of approximately $800 \mathrm{bp}$ based on gel electrophoresis. No sequence variation was detected among the five sequenced samples. DNA sequences searching and alignment using BLAST showed that D2D3 expansion segments of 28S rDNA of X. hunaniense (KF290564) from Thailand matched well (99\% similarity) with those of the X. hunaniense deposited in GenBank (EF188840, EF026090, EF188841 and EF188839), with only one nucleotide (817/818 identities), eight nucleotides (810/818 identities), nine nucleotides (809/818 identities) and ten nucleotides (808/818 identities) differences respectively, and presenting zero gap (0/818), and one gap (1/818), respectively. The next close species was $X$. italiae (FJ713153) differing by 87 nucleotides (89\% similarity, 738/825 identities), and presenting 22 gaps $(2 \%, 22 / 825)$. Surprisingly, the $28 \mathrm{~S}$ rDNA sequence of $X$. hunaniense from Thailand was only 87\% similar to $X$. brasiliense (AY601616) with 696/800 identities and 40 gaps $(5 \%, 40 / 800)$; and 81\% similar to X. radicicola (AY601622) with 651/799 identities and 27 gaps $(3 \%, 27 / 799)$.

Table 1 Morphometrics comparison of X. hunaniense female populations from Thailand and China.

\begin{tabular}{|c|c|c|c|c|c|c|}
\hline $\begin{array}{c}\text { Origin and } \\
\text { host }\end{array}$ & $\begin{array}{l}\text { Thailand, } \\
\text { Juniper }\end{array}$ & $\begin{array}{l}\text { China, grape } \\
\text { (paratypes) }^{\mathrm{a}}\end{array}$ & $\begin{array}{c}\text { China, } \\
\text { Camelliab }\end{array}$ & $\begin{array}{l}\text { China, } \\
\text { Plumc }\end{array}$ & $\begin{array}{l}\text { China, } \\
\text { Loquat }^{d}\end{array}$ & $\begin{array}{c}\text { China, } \\
\text { Pinus sp. }\end{array}$ \\
\hline $\mathrm{n}$ & 12 & 10 & 17 & 13 & 18 & 18 \\
\hline $\mathrm{L}$ & $\begin{array}{l}2.27 \pm 0.13 \\
(2.04-2.49)\end{array}$ & $\begin{array}{c}2.29 \\
(2.07-2.50)\end{array}$ & $\begin{array}{l}1.91 \pm 0.15 \\
(1.73-2.23)\end{array}$ & $\begin{array}{l}2.01 \pm 0.13 \\
(1.74-2.16)\end{array}$ & $\begin{array}{l}2.10 \pm 0.09 \\
(1.95-2.27)\end{array}$ & $\begin{array}{l}2.16 \pm 0.91 \\
(2.04-2.40)\end{array}$ \\
\hline $\mathrm{a}$ & $\begin{array}{l}40.5 \pm 3.08 \\
(36.2-45.5)\end{array}$ & $\begin{array}{c}54 \\
(51-57)\end{array}$ & $\begin{array}{c}45.0 \pm 3.7 \\
(36.9-47.7)\end{array}$ & $\begin{array}{l}42 \pm 5.3 \\
(35-49)\end{array}$ & $\begin{array}{l}46.7 \pm 3.32 \\
(41.0-53.0)\end{array}$ & $\begin{array}{c}40.2 \pm 1.7 \\
(37.3-42.6)\end{array}$ \\
\hline b & $\begin{array}{c}5.88 \pm 0.82 \\
(4.9-8.2)\end{array}$ & $\begin{array}{c}6.8 \\
(5.9-7.6)\end{array}$ & $\begin{array}{l}5.6 \pm 0.6 \\
(4.6-6.4)\end{array}$ & $\begin{array}{l}5.8 \pm 0.7 \\
(4.9-6.8)\end{array}$ & $\begin{array}{l}5.66 \pm 0.54 \\
(4.88-7.09)\end{array}$ & $\begin{array}{l}5.6 \pm 0.4 \\
(5.1-6.6)\end{array}$ \\
\hline $\mathrm{c}$ & $\begin{array}{c}35.35 \pm 4.24 \\
(29.2-46.1)\end{array}$ & $\begin{array}{c}57 \\
(53-63)\end{array}$ & $\begin{array}{c}47.5 \pm 4.8 \\
(39.2-58.5)\end{array}$ & $\begin{array}{l}49 \pm 6.3 \\
(40-59)\end{array}$ & $\begin{array}{l}40.4 \pm 4.01 \\
(32.3-47.3)\end{array}$ & $\begin{array}{c}52.8 \pm 6.6 \\
(46.6-57.9)\end{array}$ \\
\hline$c^{\prime}$ & $\begin{array}{c}2.24 \pm 0.31 \\
(1.8-2.9)\end{array}$ & $\begin{array}{c}1.5 \\
(1.2-1.7)\end{array}$ & $\begin{array}{l}1.5 \pm 0.2 \\
(1.3-2.1)\end{array}$ & $\begin{array}{l}1.6 \pm 0.21 \\
(1.2-1.9)\end{array}$ & $\begin{array}{c}1.86 \pm 0.20 \\
(1.50-2.18)\end{array}$ & $\begin{array}{l}1.4 \pm 0.1 \\
(1.0-1.6)\end{array}$ \\
\hline $\mathrm{V} \%$ & $\begin{array}{l}26.6 \pm 1.12 \\
(24.5-28.8)\end{array}$ & $\begin{array}{c}26 \\
(24-27)\end{array}$ & $\begin{array}{c}26.0 \pm 1.9 \\
(21.6-28.7)\end{array}$ & $\begin{array}{l}28 \pm 1.4 \\
(26-29)\end{array}$ & $\begin{array}{l}26.1 \pm 0.67 \\
(25.1-27.4)\end{array}$ & $\begin{array}{c}25.5 \pm 0.9 \\
(24.0-27.2)\end{array}$ \\
\hline Odontostyle & $\begin{array}{l}114.53 \pm 2.97 \\
(109.8-119.7)\end{array}$ & $\begin{array}{c}112 \\
(110-114)\end{array}$ & $\begin{array}{c}110.8 \pm 5.0 \\
(96.0-118.4)\end{array}$ & $\begin{array}{c}120 \pm 1.6 \\
(118-123)\end{array}$ & $\begin{array}{c}118.9 \pm 2.99 \\
(114.1-123.3)\end{array}$ & $\begin{array}{c}112.9 \pm 2.1 \\
(109.2-117.3)\end{array}$ \\
\hline Odontophore & $\begin{array}{l}71.5 \pm 1.86 \\
(67.4-75.0)\end{array}$ & $\begin{array}{c}71 \\
(70-75)\end{array}$ & $\begin{array}{c}63.9 \pm 6.0 \\
(60.8-73.6)\end{array}$ & $\begin{array}{l}57 \pm 2.5 \\
(54-61)\end{array}$ & $\begin{array}{l}71.6 \pm 2.55 \\
(66.7-75.8)\end{array}$ & $\begin{array}{c}70.5 \pm 1.0 \\
(68.3-71.6)\end{array}$ \\
\hline Stylet & $\begin{array}{l}186.03 \pm 2.82 \\
(181.0-191.7)\end{array}$ & $\begin{array}{c}183 \\
(180-187)\end{array}$ & $\begin{array}{c}174.9 \pm 8.4 \\
(155.2-184.0)\end{array}$ & $\begin{array}{c}177 \\
(172-184)\end{array}$ & $\begin{array}{c}190.6 \pm 3.52 \\
(183.3-195.0)\end{array}$ & $\begin{array}{c}183.4 \pm 2.4 \\
(178.6-187.9)\end{array}$ \\
\hline Tail & $\begin{array}{c}65.31 \pm 8.16 \\
(48.3-77.4)\end{array}$ & $\begin{array}{c}40 \\
(37-45)\end{array}$ & $\begin{array}{c}39.7 \pm 3.9 \\
(36.7-45.2)\end{array}$ & $\begin{array}{l}41 \pm 4.5 \\
(35-48)\end{array}$ & $\begin{array}{c}53.0 \pm 5.0 \\
(46.0-64.0)\end{array}$ & $\begin{array}{c}41.5 \pm 4.8 \\
(31.1-46.5)\end{array}$ \\
\hline $\begin{array}{l}\text { Width at lip } \\
\text { region }\end{array}$ & $\begin{array}{c}12.13 \pm 0.69 \\
(10.7-13.5)\end{array}$ & $\begin{array}{c}12 \\
(10-12)\end{array}$ & $\begin{array}{c}9.8 \pm 0.6 \\
(8.7-10.9)\end{array}$ & $\begin{array}{c}10 \pm 0.5 \\
(9-11)\end{array}$ & - & $\begin{array}{c}12.3 \pm 0.3 \\
(11.8-12.9)\end{array}$ \\
\hline $\begin{array}{l}\text { Width at } \\
\text { mid. body }\end{array}$ & $\begin{array}{c}58.27 \pm 3.94 \\
(49.2-63.8)\end{array}$ & $\begin{array}{c}42 \\
(37-44)\end{array}$ & $\begin{array}{c}42.7 \pm 4.9 \\
(37.4-55.5)\end{array}$ & $\begin{array}{l}49 \pm 5.1 \\
(43-57)\end{array}$ & - & - \\
\hline $\begin{array}{l}\text { Width at } \\
\text { anus }\end{array}$ & $\begin{array}{c}29.48 \pm 3.60 \\
(22.3-35.6)\end{array}$ & $\begin{array}{c}28 \\
(27-31)\end{array}$ & $\begin{array}{c}26.3 \pm 1.8 \\
(21.3-28.4)\end{array}$ & $\begin{array}{l}27 \pm 1.3 \\
(25-29)\end{array}$ & $\begin{array}{c}28.0 \pm 2.0 \\
(25.0-32.0)\end{array}$ & $\begin{array}{l}30.0 \pm 0.76 \\
(28.9-31.3)\end{array}$ \\
\hline
\end{tabular}

*All measurements in $\mu \mathrm{m}$, except L in mm; Means \pm SD (min. - max.), "-_"=No data.

${ }^{\mathrm{a}}$ From Wang \& Wu, 1992.

${ }^{\mathrm{b}}$ From Zheng \& Brown, 1999.

${ }^{\mathrm{c}}$ From Pan et al., 2000.

${ }^{\mathrm{d}}$ From Chen et al., 2004.

${ }^{\mathrm{e}}$ From Wu et al., 2007.

Phylogenetic relationships among Xiphinema nematodes were inferred from analyses of $28 \mathrm{~S}$ rRNA gene of a multiple edited alignment including 17 sequences using MEGA5.0, and NJ tree was constructed (Figs 2). Phylogenetic analysis of 28S rDNA of this study demonstrated that Thailand $X$. hunaniense clustered together with $X$. hunaniense populations from China. 


\section{Discussion}

The morphology of $X$. hunaniense, $X$. radicicola, and $X$. brasiliense is similar. Loof et al. (1996) considered $X$. hunaniense as a junior synonym of $X$. radicicola. However, later studies (Robbins \& Wang, 1998; Zheng \& Brown, 1999) re-established the validity of the taxonomic status of $X$. hunaniense.

A comparison of the mean and range of the morphometrics value of the female $X$. hunaniense from Thailand with from China populations (Wang \& Wu, 1992; Zheng \& Brown, 1999; Pan et al., 2000; Chen et al., 2004; Wu et al., 2007) was made. It showed that the measurement rangs of the $X$. hunaniense populations are partial overlapping. Comparing to the population fom China, the ones from Thailand has smaller c value, higher c' value and higher values in tail length and body width. The $\mathrm{a}$ and $\mathrm{b}$ values are smaller than those of paratypes (Wang \& Wu, 1992), but they are close to those of the rest populations. The odontophore and stylet are higher than those of Camellia and Plum populations, which are close to those of the remaining populations. The rest measurement values are similar to other $X$. hunaniense populations. The same situations happened to the studies of Chen et al. (Chen et al., 2007). According to the report, the Xhun8 X. hunaniense population has smaller $\mathrm{c}$ value, higher c'value and bigger tail than those of Xhun1-7 populations. Unlike the original descriptions (Wang \& Wu,1992), the Thailand female has a posterior genital tract with only single ovary.

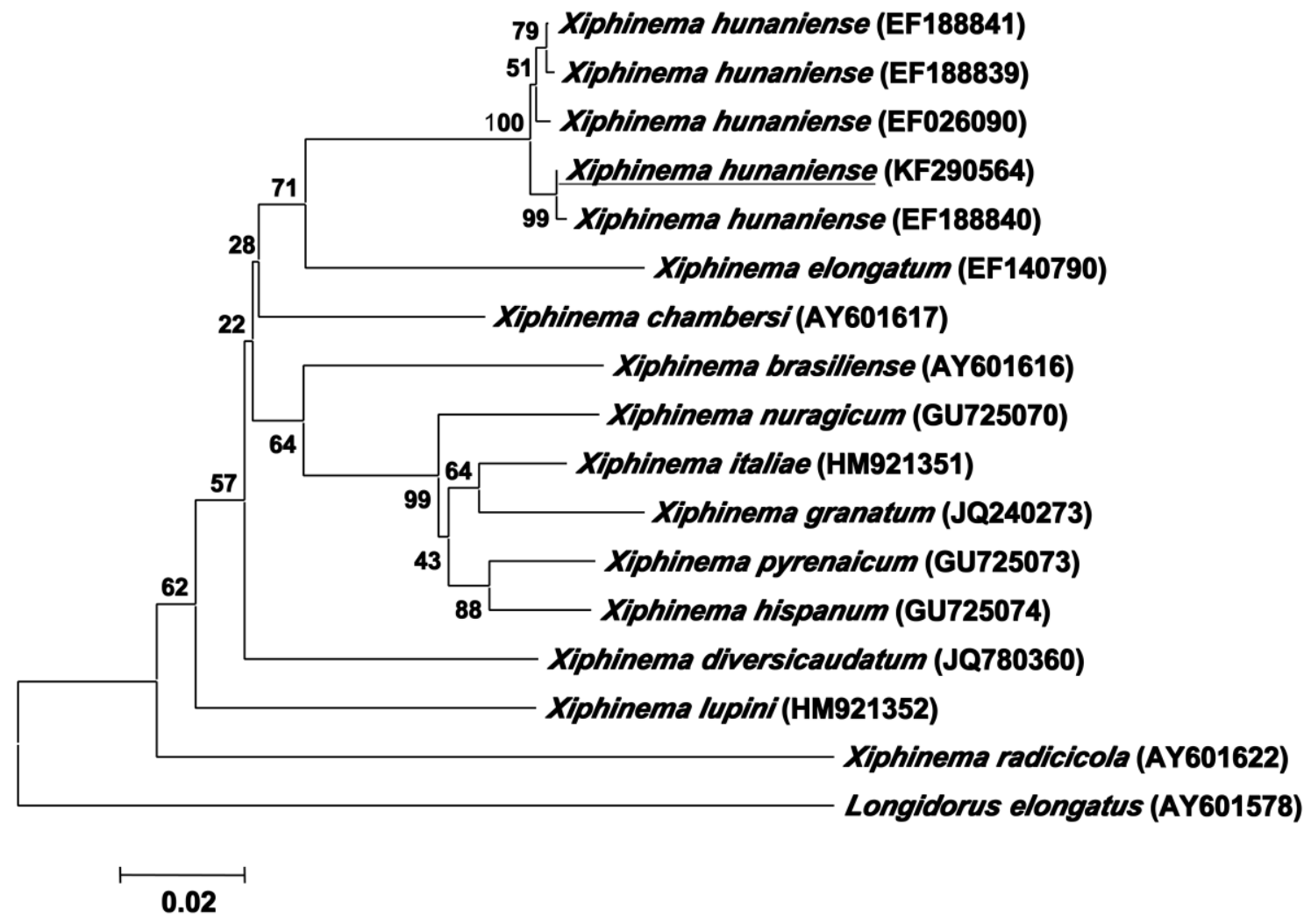

Figs 2 -Phylogenetic relationships within Xiphinema species based upon sequences of D2-D3 expansion region of the 28S rRNA gene, rooted with Longidorus elongatus. The phylogenetic tree was constructed from rDNA sequences registered with GenBank, using MEGA5 with the NeighborJoining method. Branch lengths are proportional to the amount of sequence change, which are indicated by the scale bar below the tree, and the whole numbers are bootstrap values for 1,000 analyses.Newly obtained sequence in this study is underlined. 
Furthermore, the other studies did not report that the posterior genital tract of the female divided into two branches (Zheng \& Brown, 1999; Pan et al., 2000; Chen et al., 2004; Wu et al., 2007) . The values of L [2.1 (2.0-2.2)], V\% [27 (26-28)] and stylet [187 (181-196)] of the X. brasiliense from Ceylon (Corn \& Sher, 1972) are close to those of Thailand $X$. hunaniense. And a comparison of the means and ranges of $X$. hunaniense (Table 1) with those of $X$. radicicola (Luc, 1981; Razak \& Loof, 1998) was also made. The measurement ranges of the two species are also partial overlapping. The means analysis with one-way anova demonstrated that the c, c', V\%, tail length, width at anus values have a certain influence on differentiating the two species, and the rest measurement values have no significant influence. Perhaps this is one reason that the two species are often confused (Loof et al., 1996). Whether variable morphology and morphometrics within and between populations of $X$. hunaniense or similar morphology and morphometrics among $X$. hunaniense, $X$. brasiliense and $X$. radicicola indeed affect the identification results only based on the morphology and morphometrics. The molecular data of rDNA sequences is more convincing than the morphometrics data, because it is stable within and between populations of $X$. hunaniense (Chen et al., 2004; Wu et al., 2007). Therefore, X. hunaniense identification based on sequencing of 28S rDNA combining with morphological and morphometrical data is more rational.

\section{Acknowledgements}

The authors thank Dr. Zhuo Kan, Laboratory of Plant Nematology, College of Natural Resource and Environment, South China Agricultural University, China for morphological measurement and review on the identification results.

\section{References}

Brown DJF, Boag B. 1988-An examination of methods used to extract virus-vector nematodes (Nematoda: Longidoriae and Trichodoridae) from soil samples. Nematologia Mediterranea 16, 93-99.

Chen DY, Ni HF, Yen JH, Cheng YH, Tsay TT. 2004-Identification and variation of Xiphinema hunaniense populations from Taiwan. Plant Pathology Bulletin 13, 155-166.

Cohn E, Sher SA. 1972-A contribution to the taxonomy of the genus Xiphinema Cobb, 1913. Journal of Nematology 4, 36-65.

Hall TA. 1999-BioEdit: a user-friendly biological sequence alignment editor and analysis program for windows 95/ 98NT. Nucleic Acids Symposium Series 41, 95-98.

Hooper DJ. 1986-Handling, fixing, staining and mounting nematodes. In: Laboratory methods for work with plant and soil nematodes (Southery J Eds.). pp. 59-80. reference book: 402. London, Her Majesty's Stationery Office Press.

Loof PAA, Luc M, Baujard P. 1996-A revised polytomous key for the identification of species of the genus Xiphinema Cobb, 1913 (Nematoda: Longidoridae) with exclusion of the $X$. americanum group: Supplement 2. Systematic Parasitology 33, 23-29.

Luc M. 1981-Observations on some Xiphinema species with the female anterior genital branch reduced or absent (Nematoda: Longidoridae). Revue de Nématologie 4, 157-167.

Pan CS, Zheng JW, Zhou XP, Neilson R, Brown DJF. 2000-Preliminary assessment of the occurrence of longidorid and trichodorid nematodes (Nematoda: Longidoridae and Trichodoridae) in Xiamen, Fujian Province, China. Russian Journal of Nematology 8, 153159.

Razak AR, Loof PAA. 1998-The genus Xiphinema Cobb, 1913 (Nematoda: Longidoridae) in western Malaysia. Fundamental and Applied Nematology 21, 413-428.

Robbins RT, Wang S. 1998-A comparison between Xiphinema radicicola and X. hunaniense. In: Program and abstracts of the $24^{\text {th }}$ international symposium of the European Society of Nematologists, 4-9 August 1998, Dudee, Scotland, pp 100.

Siddiqi MR. 2000-Tylenchida: parasites of plants and insects (2nd ed.). Walling- ford, CABI Press. 
Tamura K, Peterson D, Peterson N, Stecher G, Nei M, Kumar S. 2011-MEGA5: molecular evolutionary genetics analysis using maximum likelihood, evolutionary distance, and maximum parsimony method. Molecular Biology and Evolution 28, 2731-2739.

Thompson JD, Higgins DG, Gibson TJ. 1994-Clustal W: improving the sensitivity of progressive multiple sequence alignment through sequence weighting, positionsspecific gap penalties and weight matrix choice. Nucleic Acids Research 22, 4673-4680.

Wang S, Wu X. 1992-Two species of Xiphinema Cobb, 1913 (Dorylaimida: Longidoridae) from around grape roots in China. Acta Phytopathology Sinica 22, 117-123 .

Wu Y, Zheng J, Robbins RT. 2007-Molecular characterization of a Xiphinema hunaniense population with morphometric data of all four juvenile stages. Journal of Nematology 39, 3742 .

Zheng J, Brown DJF. 1999-Xiphinema insigne Loos, 1949 and X. hunaniense Wang \& Wu, 1992 from Hangzhou, China, and synonymization of $X$. savaryi Lamberti, Troccoli and Agostinelli, 1997 with $X$. insigne, and $X$. siamense Lamberti, Troccoli \& Agrostinelli, 1997 with $X$. radicicola Goodey, 1936 (Nematoda: Longidoridae). Russian Journal of Nematology 7, 127137. 